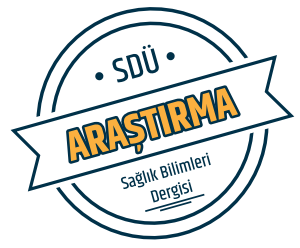

Sdü Sağlık Bilimleri Dergisi / Cilt 10 Sayı 3 / 2019

\title{
Genotoxic and Apoptotic Effects of Heavy Metal Mixture on Human Aortic Vascular Smooth Muscle Cell Line
}

\section{Ağır Metal Miksinin İnsan Aort Vasküler Düz Kas Hücrelerinde Genotoksik ve Apoptotik Etkileri}

\author{
Emrah Yavuz ${ }^{1}$, Zeynep Banu Doğanlar² \\ ${ }^{1}$ Department of Biotechnology and Genetics, Trakya University Institute of Science, Edirne, Turkey. \\ ${ }^{2}$ Department of Medical Biology, Trakya University School of Medicine, Edirne, Turkey.
}

\begin{abstract}
Objective: Heavy metals are the most common pollutants with specific gravity greater than $5 \mathrm{~g} \mathrm{~cm}^{-3}$. Human exposure to heavy metals occurs mostly through the consumption of food and water containing heavy metals. Metals that enter the body via drinking water may cause genotoxicity and various diseases. Therefore, permissible limits of heavy metals in water for human consumption have been determined by laws and regulations. Our study aimed to investigate the effects of a mix of metals $(\mathrm{Cu}, \mathrm{Zn}, \mathrm{Pb}$ and $\mathrm{Fe})$ at permissible limits in drinking water on aortic smooth muscle cells (TG-HAVSMC) with at molecular level.
\end{abstract}

Material-Method: A metal mix at the permissible concentration for drinking water and 10-fold higher concentration were exposed to human aortic smooth muscle for 24 and 48 hours, and gene expression of antioxidant enzymes (CuZn-SOD, Mn-SOD, CAT, GST), heat-shock proteins (HSP27, HSP60, HSP70) and apoptosis pathway (p53, PUMA, BCL2, BAX, Cyt-C, Casp-3, TNF- $\alpha$, Casp-8, DR4, DR5) cell cycle control (p21) and DNA repair (EXO1) were investigated in addition to RAPD-DNA polymorphism.

Results: It was determined that heavy metal exposure caused increase in the DNA polymorphism, apoptotic cell ratios and enhanced antioxidant and apoptosis pathway gene expression in cells.

Conclusions: In conclusion, the mix consisting of heavy metals at permissible limits in drinking water has been shown to cause oxidative stress, genotoxicity and apoptosis in human aortic smooth muscle cells. Considering that apoptosis in vascular smooth muscle cells plays a role in the pathophysiology of diseases such as arteriosclerosis and hypertension, we believe it would be beneficial to assess these limits through extensive investigations in further studies.

Keywords: Human Aortic Vascular Smooth Muscle Cell, Cardiovascular Toxicity, Heavy Metal, Gen Expression, Apoptosis.

\section{Introduction}

There is no doubt that environmental factors have important effects on the health and wellbeing of humans who constantly interact with the environment through their lives. Environmental pollution is one of the most important

\section{Özet}

Amaç: Ağır metaller özgül ağırlıkları $5 \mathrm{~g} \mathrm{~cm}^{-3}$ ten yüksek olan en yaygın kirleticilerdir. Insanların ağır metallere maruziyeti genellikle ağır metal içeren su ve besinlerin tüketilmesi yolu ile olmaktadır. Içme suyu yolu ile vücuda giren metaller genotoksisite ve çeşitli hastalıklara neden olurlar. Bu nedenle insani tüketim amaçlı kullanılan sularda ağır metallerin kabul edilebilir limitleri kanun ve yönetmelikler ile belirlenmiştir. Bizim çalışmamız içme suyunda izin verilen limitlerde metal miksinin $(\mathrm{Cu}, \mathrm{Zn}, \mathrm{Pb}$ ve $\mathrm{Fe})$ insan aort düz kas hücrelerinde (TG-HA-VSMC) etkilerini moleküler düzeyde araştırmayı amaçlamıştır.

Materyal-Metot: İnsan aort düz kas hücrelerine içme sularında izin verilen düzey ve 10 kat yüksek konsantrasyonda metal miksi 24 ve 48 saat süre ile uyguland 1 ve RAPD-DNA polimorfizmine ilaveten antioksidan enzimler ( $\mathrm{CuZn}$-SOD, Mn-SOD, CAT, GST), 1s1 şok proteinleri (HSP27, HSP60, HSP70), apoptoz yolak (p53, PUMA, BCL2, BAX, Cyt-C, Casp-3, TNF- $\alpha$, Casp-8, DR4, DR5) hücre döngüsü kontrol (p21) DNA tamir (EXO1) gen ifadeleri belirlendi.

Bulgular: Ağır metal uygulamasının DNA polimorfizminde, apoptotik hücre oranında, antioksidan ve apoptoz yolağı gen ifadelerinde artışa neden olduğu belirlendi.

Sonuç: Sonuç olarak, içme sularında izin verilen limitlerde ağır metal karışımının aorta düz kas hücrelerinde oksidatif stres, genotoksisite ve apoptoza neden olduğu belirlendi. Vasküler düz kas hücrelerinde apoptozun arteroskleroz, hipertansiyon gibi hastalıkların patofizyolojisinde rol oynadığı göz önünde bulundurulduğunda bu limitlerin daha kapsamlı çalışmalarda araştırılarak değerlendirilmesi gerektiği düşünüldü.

Anahtar kelimeler: İnsan Aort Vasküler Düz Kas Hücresi, Ağır Metal, Kardiyovasküler Toksisite, Gen İfadesi, Apoptoz.

problems affecting human health. Heavy metals are a major cause of toxicity for people facing a wide range of diseases as a result of accumulation of various pollutants in the body due to exposure to contaminated air, water or soil in their environment (1). The release of heavy metal contaminated

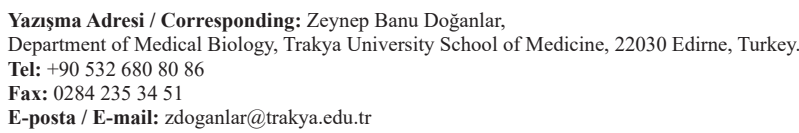


wastes to soil and waters, heavy metals enters into our food web (2). In addition, the increase in petroleum waste, pesticides, fertilizers and household waste, which are not transformed in the nature, together with increasing population, leads to environmental pollution and this may show toxic effects even at low concentrations in humans (3).

Heavy metals taken via food, water and inhalation accumulate in tissues and create oxidative stress through enhanced free radical formation in cells with increasing age. In particular, heavy metals such as $\mathrm{Cd}, \mathrm{Pb}, \mathrm{Fe}$ and $\mathrm{Cu}$ may have toxic effects on cells as a result of the accumulation in the body (4). The accumulation of heavy metals in the body through air, water and nutrients may result in a variety of diseases in humans. Heavy metal toxicity can cause osteoporosis, central nervous system and respiratory tract diseases, jaundice, impaired vision and hemophilia. Especially the effects on the circulatory system may lead to cardiovascular disorders such as arrhythmia, hypertension and anemia. Heavy metal toxicity is also associated with tumor formation in tissues (5).

Although cardiovascular system is not the primary target of heavy metals, these metals cause oxidative stress and disrupt antioxidant systems, thereby resulting in cardiovascular toxicity (6). Since the genotoxic effects that may occur due to treating aortic smooth muscle cells with heavy metals may be involved in the development of circulatory system and cardiovascular diseases such as hypertension, arrhythmia, tachycardia, heart failure, diabetes, heart attack, heart spasm and sudden cardiac arrest, the present study aimed investigate the antioxidant- and apoptosis-related effects of a $\mathrm{Fe}, \mathrm{Cu}, \mathrm{Cd}$ and $\mathrm{Pb}$ mix administered to aortic smooth muscle cells $(\mathrm{T} / \mathrm{G}$ HA-VSMC; ATCC ${ }^{\circledR}$ CRL-1999TM) at permissible limits in drinking water.

\section{Material and Methods \\ Cell Culture and Treatment}

Human aortic smooth muscle cell line (T/G HA-VSMC ATCC $(C R L-1999)$ was used in this study. Cell culture and treatments were performed in sterile incubators at $37^{\circ} \mathrm{C}$ with $5 \% \mathrm{CO}_{2}$. Cells were cultured in DMEM: F-12 medium supplemented with $0.03 \mathrm{mg} / \mathrm{ml}$ Endothelial Cell Growth Supplement and 10\% fetal calf serum (Gibco Life Technologies), $2 \mathrm{mM}$ glutamine (Gibco-Life Technologies) and $1 \%$ final concentration of penicillin / streptomycin (Invitrogen, Life Technologies).

For metal treatments early passages (five to seven) of cells seeded at $75 \mathrm{~cm}^{2}$ polystyrene tissue culture flasks to $80 \%$ to $90 \%$ confluence. Metal mix concentrations were determined based on national Regulation on Water for Human Consumption. According to this regulation, permitted limits have been determined as follows: $5 \mu \mathrm{g} / \mathrm{L}$ for $\mathrm{Cd}, 10 \mu \mathrm{g} / \mathrm{L}$ for $\mathrm{Pb}, 200 \mu \mathrm{g} / \mathrm{L}$ for $\mathrm{Fe}$ and $2000 \mu \mathrm{g} / \mathrm{L}$ for $\mathrm{Cu}$. In the present study, metals were administered as a mix since exposure to these metals often occurs through mixtures. Administration was performed for 24 and 48 hours at the limits specified by the regulation (M1) and at a 10-fold higher concentration (M2).

\section{Genetic Analyses \\ DNA Isolation and RAPD Analyses}

Total DNA of control and heavy metal mixture exposed cell was isolated from $25-\mathrm{cm}^{2}$ tissue culture plates using a DNeasy Tissue Blood Kit (Qiagen, Hilden, Germany) according to the manufacturer's instructions. Template DNA equals $25 \mathrm{ng} / \mathrm{mL}$ with the nuclease-free water to PCR reaction. Totally, $25 \mathrm{~mL}$ PCR reactions were performed using $2 \mathrm{~mL}$ DNA, $0.5 \mathrm{~mL}$ of each primer (Table 1), $12.5 \mathrm{~mL}$ of Amplitaq gold, and ultrapure water. After the DNA amplification, $10 \mathrm{~mL}$ of PCR products were loaded onto a $2 \%$ agarose gel with ethidium bromide in 2xTris Acetate EDTA buffer (Invitrogen, 24710030). Geneaid 100 bp DNA ladder (100-3.000 bp) was used as molecular standards. RAPD band were visualized and analysed with Vilber Lourmat, Quantum transluminator and BIO-PROFIL, BIO-1D++ image analyses software.

\section{RNA Isolation and Quantitative Real-time PCR (qRT- PCR) Analyses}

RNA isolation from the cells in the control and study groups was performed at 24 and 48 hours after treatment according to the kit protocol of Ambion ${ }^{\circledR}$ RNA Kit (Life Technologies). High Capacity cDNA Reverse Transcription Kit (Applied Biosystems) was used to obtain complementary DNAs from these RNAs.

The changes in the gene expression of $\mathrm{CuZn}$-SOD, Mn-SOD, CAT, GST, HSP27, HSP60, HSP70, p53, PUMA, BCL2, BAX, Cyt-C, Casp-3 TNF- $\alpha$, Casp-8, DR4, DR5, p21 and EXO1 were analyzed using the primers presented in Table 1 by means of qRT-PCR in the control and study groups. The expression of GAPDH (glyceraldehyde-3-phosphate dehydrogenase) gene was used as the endogenous control.

\section{Annexin V / Propidium Iodide Staining Assay}

Apoptosis assay in the control and study groups was performed with the cells harvested at 24 and 48 hours after treatment with Tali ${ }^{\circledR}$ Image-Based Cytometer using Tali ${ }^{\circledR}$ Apoptosis Kit-Annexin V (AlexaFluor ${ }^{\circledR}$ 488) and Propidium Iodide (Life Technologies) kit. Briefly, cells trypsinized from flasks and centrifuged for 2 minutes at 1,000 g. The pellet were incubated with Annexin-binding buffer containing Annexin V in the dark for 20 minutes, and the supernatant was discarded after centrifugation. Annexin-binding buffer containing propidium iodide was added onto the pellet and incubated in the dark for 5 minutes. After the incubation, Tali ${ }^{\circledR}$ Image Based Cytometer (Invitrogen) was used for analysis.

\section{Statistical Analysis}

Each experiment was performed in three replicate in all groups. The differences in the gene expressions were compared using T-test and analysis of variance (ANOVA) with Duncan's separation of means test using SPSS 20 software at a significance level of $p \leq 0.05$. SPSS 20 (university-licensed) statistical package program was used for all analyzes.

\section{Results}

Metal mix treatment caused a statistically significant decrease in the ratio of viable cells compared to the control 
Table 1. Genes, primer sequences and PCR conditions of qRT-PCR and RAPD

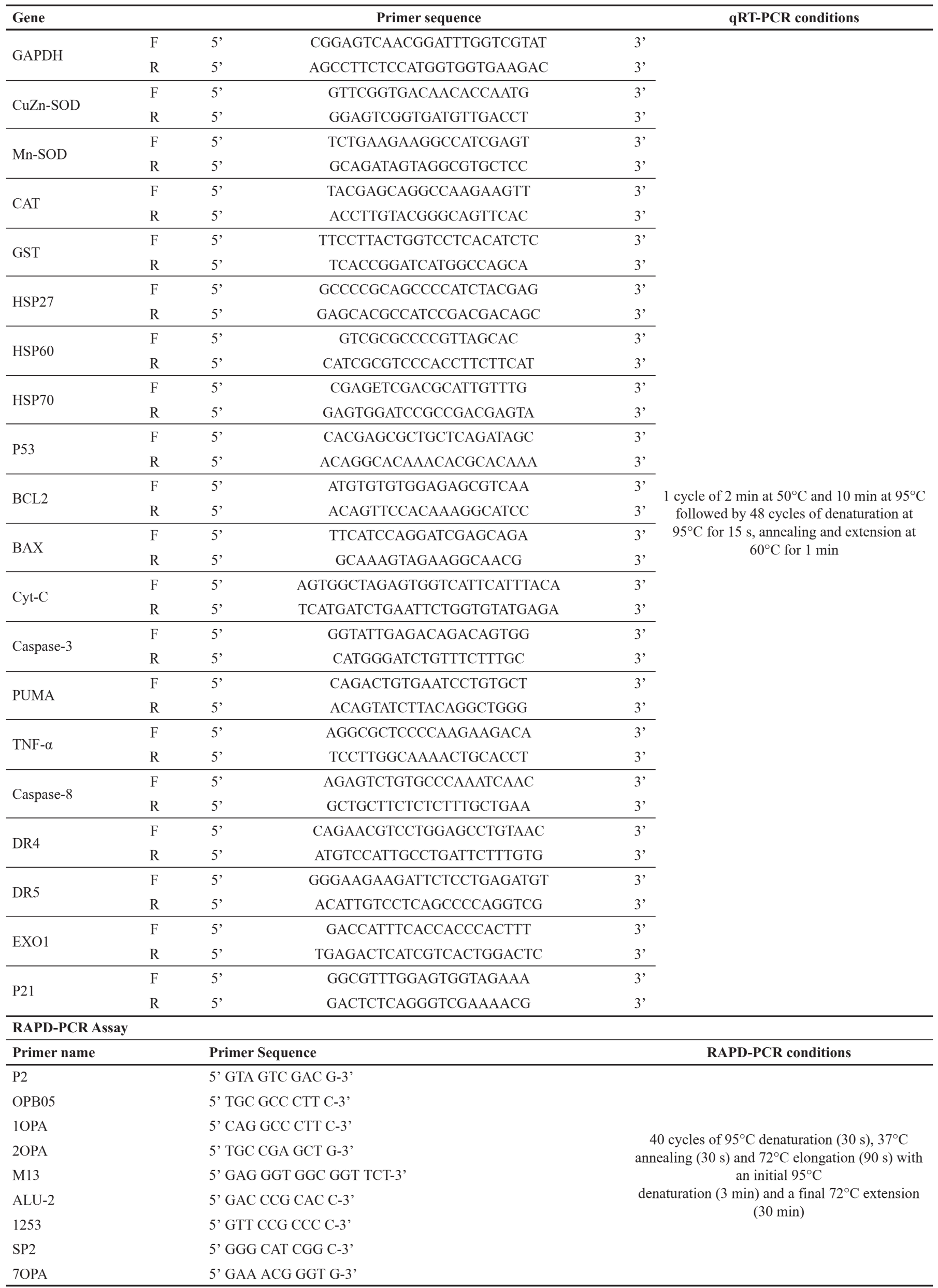


group in addition to an increase in the proportion of dead and apoptotic cells (Figure 1). The highest rate of apoptotic cells was observed at 24 hours with the M2 concentration $(39.3 \%)$. The ratio of dead cells was $22.6 \%$ at 48 hours with the M1 concentration. The effect of metal mixes on antioxidant enzymes was evaluated by gene expression of superoxide dismutase ( $\mathrm{Cu}-\mathrm{Zn}$ SOD and Mn-SOD), catalase (CAT) and glutathione-S-transferase (GST) enzymes. CuZn SOD gene expression was increased both dose and time dependent manner (Figure 2). The highest gene expression was determined at the M2 concentration with both exposure time. Mitochondrial Mn-SOD gene expression showed a statistically significant increase only at the highest concentration compared to the control group $24 \mathrm{~h}$ after exposure. At 48 hours, it was significantly higher than the control group at both concentrations. GST gene expression showed a significant increase compared to the control only at the M2 concentration at 24 hours after administration while it was increased at both concentrations at 48 hours. In the present study, we demonstrated DNA damage with RAPD (random amplified polymorphic DNA) analysis (Figure 3). This analysis revealed newly formed bands and bands that disappear as well as changes in band intensities (Table 2). In our study, overexpression of the DNA repair gene, EXO1, was detected only with M2 at 24 hours (5.3-fold) and both with M1 and M2 at 48 hours (24.9- and 44.9-fold, respectively) in HAVSMC $(p<0.05)$. The effect of metal mixes on heat-shock proteins in HAVSMC was evaluated with the gene expression of HSP27, HSP60 and HSP70 (Figure 4). HSP27 expression was increased only at 48 hours of administration at the M1 concentration (11.5-fold compared to control). Increased HSP60 gene expression was observed with increasing concentration and in a time-dependent manner. While HSP70 gene expression was significantly decreased compared to the control group at 24 hours with both concentrations, it was increased at 48 hours only with M1 administration. When all HSPs were evaluated together, each was observed to reach the highest gene expression level at 48 hours with M1. The greatest increase was detected for the stress-specific HSP70 (28.2-fold compare to control).

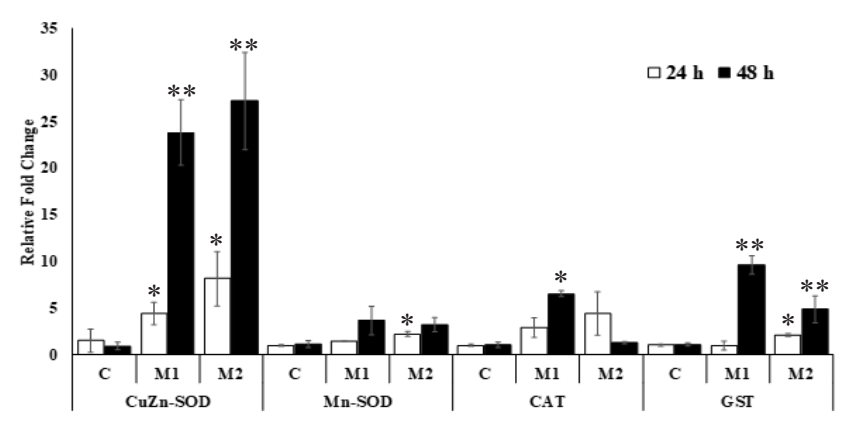

Figure 2. The mRNA levels of CuZn-SOD, Mn-SOD, CAT and GST genes in metal mixture exposed HAVSMC cells for $24-48 \mathrm{~h}$. Asterisk indicates significantly different values compared to their respective controls analysed by one-way ANOVA, Duncan test $(p<0.05)$.
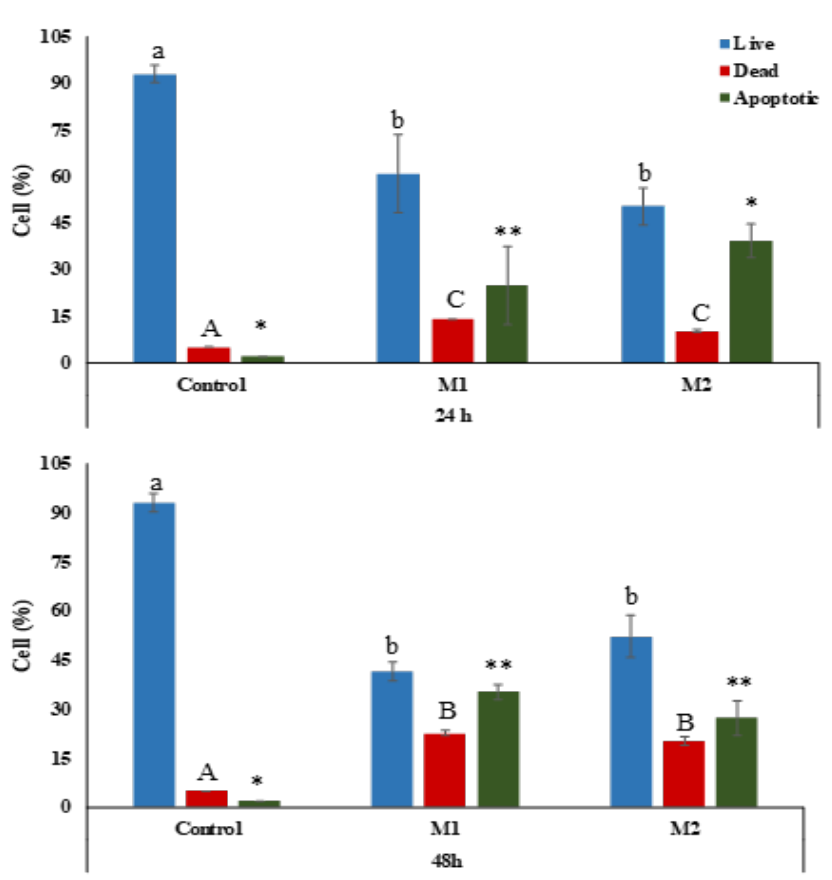

Figure 1. Percentage result of live, dead and apoptotic cells stained with annexin $\mathrm{V} /$ propidium iodide as determined using an Tali image based cytometer. All data are given as the mean values of percentages for each group \pm SE. Different letters or asteriks indicates significantly different values compared to their respective controls analysed by oneway ANOVA and Duncan test $(\mathrm{p}<0.05)$.
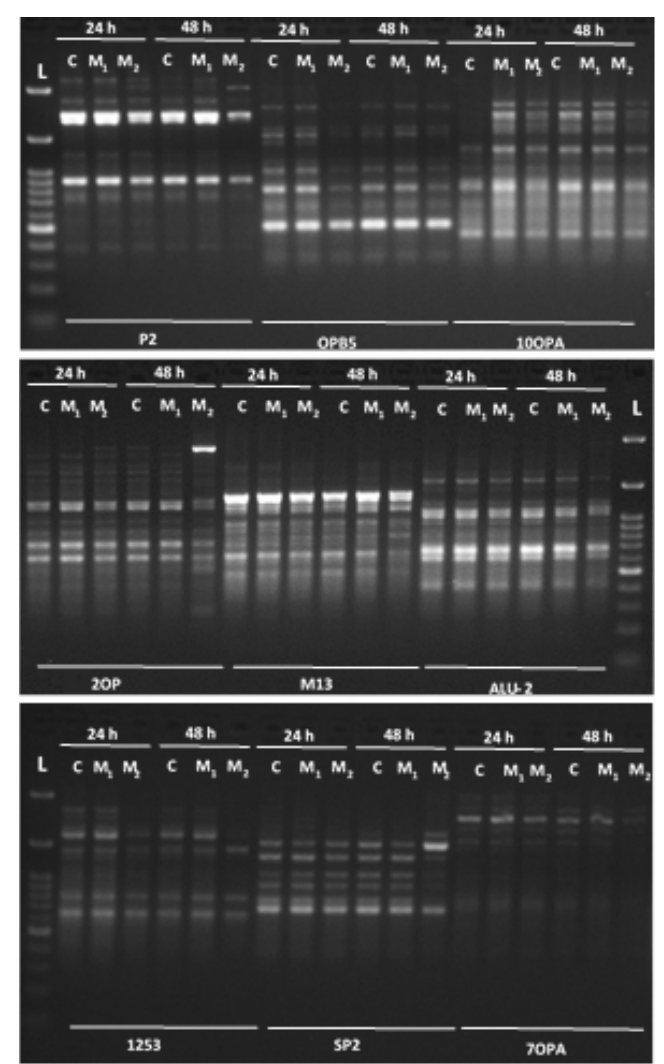

Figure 3. The random amplified polymorphic DNA (RAPD) assay band profiles of total genomic DNA belongs to heavy metal mixture treated HAVSMC cell line for 24 and 48 h. M1 (Mix 1), M2 (Mix 2), Ladder (L) Geneaid 100-bp DNA ladder (100-3000 bp). 
Table 2. Changes in the RAPD profiles based on the appearance (A) and disappearance (D) of bands with specific molecular sizes (bp) using nine primers in the control and heavy metal mix-exposed HAVSMC cells

\begin{tabular}{|c|c|c|c|c|}
\hline \multicolumn{5}{|c|}{ Concentrations } \\
\hline Primers & Control & & Mix 1 & Mix 2 \\
\hline \multicolumn{5}{|l|}{$24 . \mathrm{h}$} \\
\hline \multirow{2}{*}{ P2 } & \multirow{2}{*}{$\begin{array}{l}3331 ; 2683 ; 2185 ; 2005 ; 1537 ; 1231 ; 917 ; 757 ; \\
381\end{array}$} & $\mathrm{~A}$ & 1258 & - \\
\hline & & $\mathrm{D}$ & $1537 ; 1231 ; 381$ & $2005 ; 1537 ; 381$ \\
\hline \multirow{2}{*}{ OPB05 } & \multirow{2}{*}{$\begin{array}{l}2484 ; 1789 ; 1616 ; 1471 ; 1141 ; 1029 ; 842 ; 663 ; \\
521\end{array}$} & A & 2541 & 538 \\
\hline & & $\mathrm{D}$ & 2484 & $2484 ; 1471 ; 1141 ; 1029 ; 663 ; 521$ \\
\hline \multirow{2}{*}{ 1OPA } & \multirow{2}{*}{$1341 ; 842 ; 467$} & A & $2569 ; 2132 ; 1931 ; 1313$ & $2512 ; 2132 ; 198 ; 170$ \\
\hline & & $\mathrm{D}$ & 1341 & - \\
\hline \multirow{2}{*}{ 2OPA } & \multirow{2}{*}{$\begin{array}{l}2798 ; 2512 ; 2158 ; 1931 ; 1299 ; 1231 ; 1019 ; 950 \\
892 ; 800 ; 656\end{array}$} & A & $2541 ; 1722 ; 1327 ; 198$ & $2654 ; 2429 ; 2005 ; 766$ \\
\hline & & $\mathrm{D}$ & $2798 ; 2512 ; 1931 ; 1299$ & $2512 ; 1931 ; 800$ \\
\hline \multirow{2}{*}{ M13 } & \multirow{2}{*}{$\begin{array}{l}2106 ; 1370 ; 1285 ; 1231 ; 1729 ; 1009 ; 942 ; 800 \\
670 ; 549\end{array}$} & A & 2158;1767;1413;1191;908; & $1413 ; 908 ; 825 ; 724 ; 648$ \\
\hline & & $\mathrm{D}$ & $2106 ; 1285 ; 1231 ; 1129 ; 942 ; 549$ & $2106 ; 1285 ; 1231 ; 942 ; 800 ; 670 ; 549$ \\
\hline \multirow{2}{*}{ ALU-2 } & \multirow{2}{*}{$1767 ; 1060 ; 992 ; 700 ; 634 ; 452$} & A & $1980 ; 1744 ; 1218 ; 791$ & $1244 ; 1117 ; 774$ \\
\hline & & $\mathrm{D}$ & $1767 ; 992$ & 992 \\
\hline \multirow{2}{*}{1253} & \multirow{2}{*}{$2526 ; 2234 ; 1740 ; 1381 ; 800 ; 624$} & A & $2297 ; 653$ & $1820 ; 666$ \\
\hline & & $\mathrm{D}$ & 624 & $2526 ; 2234 ; 1740 ; 1381 ; 624$ \\
\hline \multirow{2}{*}{ SP2 } & \multirow{2}{*}{$\begin{array}{l}2362 ; 2140 ; 1875 ; 1688 ; 1398 ; 1128 ; 979 ; 830 \\
741\end{array}$} & A & $1820 ; 1415 ; 849$ & $2049 ; 1714 ; 1415 ; 849$ \\
\hline & & $\mathrm{D}$ & $2362 ; 2140 ; 1875 ; 1398 ; 830$ & $2362 ; 2140 ; 1875 ; 1688 ; 1398 ; 830$ \\
\hline \multirow{2}{*}{ 7OPA } & \multirow{2}{*}{$3270 ; 3000 ; 2626 ; 2234 ; 1875 ; 1128 ; 810$} & A & 3330 & $3390 ; 2897 ; 2297 ; 1932$ \\
\hline & & $\mathrm{D}$ & $3270 ; 1128$ & $3000 ; 1875 ; 1128$ \\
\hline \multicolumn{5}{|l|}{$48 . \mathrm{h}$} \\
\hline \multirow{2}{*}{$\mathrm{P} 2$} & \multirow{2}{*}{$3331 ; 2654 ; 2185 ; 2055 ; 1258 ; 925 ; 766$} & A & $2005 ; 1244$ & $3153 ; 2265$ \\
\hline & & $\mathrm{D}$ & $2055 ; 1258$ & $3331 ; 2185 ; 1258 ; 766$ \\
\hline \multirow{2}{*}{ OPB05 } & \multirow{2}{*}{$2541 ; 1767 ; 1596 ; 1105 ; 1019 ; 933 ; 842 ; 527$} & A & $2512 ; 1009 ; 532$ & $2573 ; 1906 ; 1576$ \\
\hline & & $\mathrm{D}$ & $2541 ; 1019 ; 527$ & $2541 ; 1767 ; 1596 ; 1105 ; 933$ \\
\hline \multirow{2}{*}{ 1OPA } & \multirow{2}{*}{$2569 ; 2132 ; 1931 ; 1722 ; 1327 ; 825 ; 457$} & A & $2055 ; 817$ & 2484 \\
\hline & & $\mathrm{D}$ & $1931 ; 825$ & $2569 ; 1931$ \\
\hline & $2826 \cdot 2457 \cdot 2185 \cdot 2030 \cdot 1835 \cdot 1313 \cdot 1218 \cdot 950$. & A & $2292 ; 2081 ; 1537 ; 1413 ; 1009$ & $1327 ; 933 ; 808 ; 700 ; 634 ; 566$ \\
\hline 2OPA & $\begin{array}{l}2826 ; 245 / ; 2185 ; 2030 ; 1835 ; 1313 ; 1218 ; 950 ; \\
850 ; 774 ; 663\end{array}$ & $\mathrm{D}$ & $2185 ; 2030$ & $\begin{array}{l}2457 ; 2185 ; 2030 ; 1835 ; 1313 ; 950 ; 8 \\
50 ; 734 ; 663\end{array}$ \\
\hline 13 & $1442 \cdot 1341 \cdot 1120 \cdot 082 \cdot 807 \cdot 817 \cdot 602.560$ & A & $1258 ; 1179 ; 1060 ; 741 ; 678$ & $1204 ; 1060$ \\
\hline M113 & $1442 ; 1341 ; 1129 ; 983 ; 892 ; 81 / 693 ; 560$ & $\mathrm{D}$ & $1341 ; 1129 ; 983 ; 817 ; 693$ & $1129 ; 817 ; 560$ \\
\hline & $1931 \cdot 1744 \cdot 1341 \cdot 1204 \cdot 1071 \cdot 1000 \cdot 783700 \cdot 6$ & A & $1271 ; 1094 ; 648$ & $2913 ; 724$ \\
\hline ALU-2 & $\begin{array}{l}1931,1 / 44,1341,1204,10 / 1,1000 ; / 80, / 00 ; 0 \\
56 ; 467\end{array}$ & $\mathrm{D}$ & $1341 ; 783 ; 656$ & $\begin{array}{l}1931 ; 1341 ; 1204 ; 1071 ; 1000 ; 783 \\
, 700\end{array}$ \\
\hline 1253 & $2503 \cdot 1820 \cdot 1483 \cdot 840 \cdot 673$ & A & $2394 ; 1961$ & 849 \\
\hline $12 J 3$ & ( & $\mathrm{D}$ & - & $2593 ; 840$ \\
\hline $\mathrm{CD} 2$ & 2010.1714 .1422 .1157 .000 .050 .764 & A & 753 & $1688 ; 1398$ \\
\hline $\mathrm{SP2}$ & 2019;1/14;1432;115/;990;858;/64 & $\mathrm{D}$ & $2019 ; 764$ & $1714 ; 1432 ; 858$ \\
\hline 7001 & 2020006600002661000000 & A & $2693 ; 1847$ & $2932 ; 2693$ \\
\hline /OPA & 3330;2966;2626;2266;1903;800 & $\mathrm{D}$ & $3330 ; 2626 ; 1903$ & $3330 ; 2966 ; 2626 ; 2266 ; 1903 ; 800$ \\
\hline
\end{tabular}




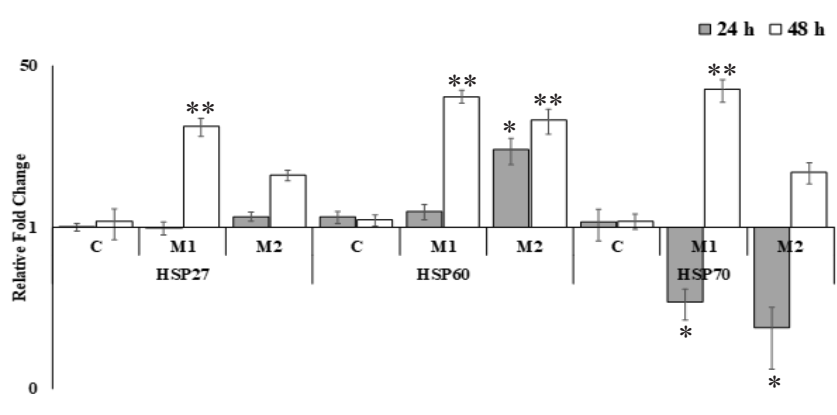

Figure 4. The mRNA levels of HSP genes in metal mixture exposed HAVSMC cells for 24-48 h. Asterisk indicates significantly different values compared to their respective controls analysed by one-way ANOVA, Duncan test $(\mathrm{p}<0.05)$.
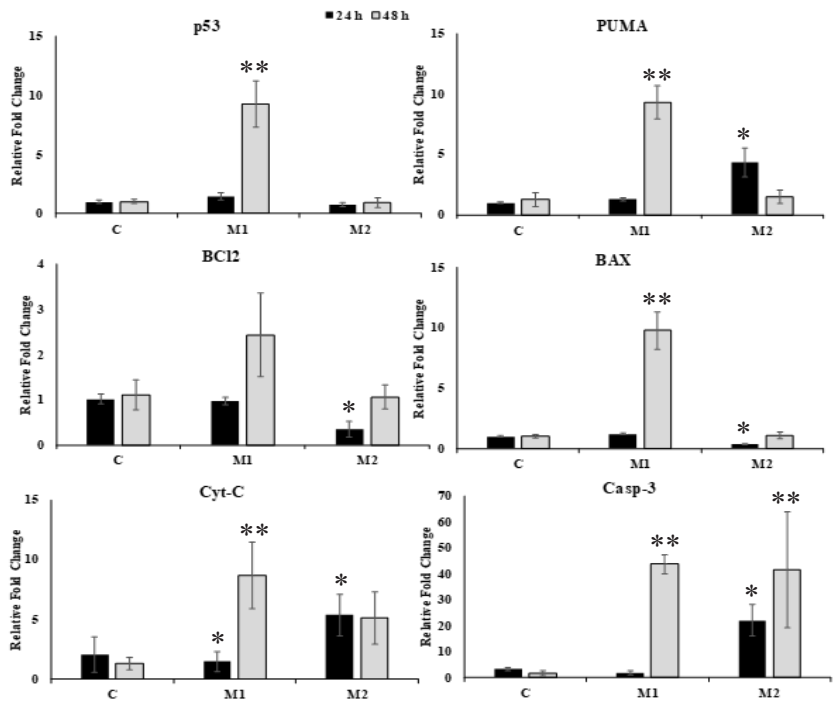

Figure 5. The mRNA levels of p53, PUMA, BCL2, BAX, Cyt-C, Casp3 genes in metal mixture exposed HAVSMC cells for $24-48 \mathrm{~h}$. Asterisk indicates significantly different values compared to their respective controls analysed by one-way ANOVA, Duncan test $(p<0.05)$.

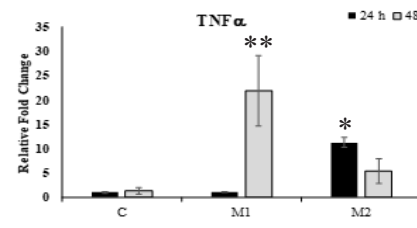

DR4
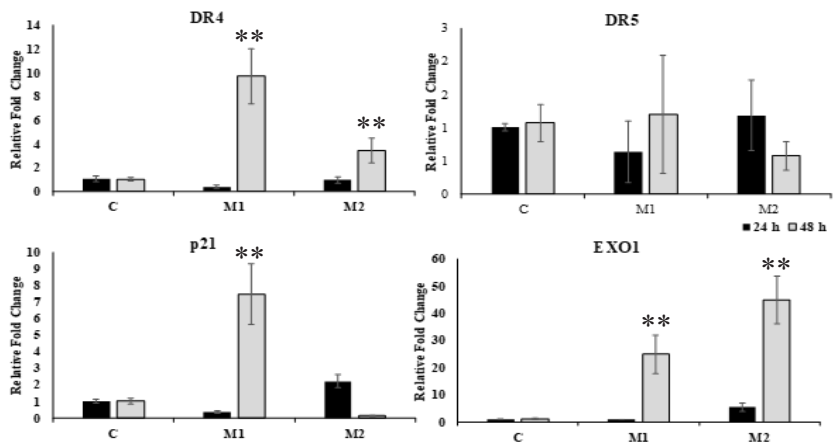

Figure 6. The mRNA levels of TNF- $\alpha$, Casp-8, DR4, DR5, p21 and EXO1 genes in metal mixture exposed HAVSMC cells for 24-48 h. Asterisk indicates significantly different values compared to their respective controls analysed by one-way ANOVA, Duncan test $(\mathrm{p}<0.05)$.
In our study, the effect of heavy metal mixes on apoptotic processes was determined based on gene expression in the mitochondrial apoptosis (intrinsic) pathway as well as the death receptor pathway (Figure 5 and 6). Overexpression of the p53 gene was observed especially at 48 hours after M1 administration in HAVSMC cells (9.2-fold increase compared to the control). Again, at the same concentration and exposure time, statistically significant increases were determined in gene expressions of the apoptosis inhibitor BCL2 and PUMA, a proapoptotic factor (2.2- and 9.2-fold vs. control, respectively). In this setting, apoptosis regulator BAX was increased by 9.7 -fold compared to the control group and overexpression of cytochrome-C was detected (8.67-fold vs. control) as a result of the reduced BCL2/BAX ratio. Caspase- 3 overexpression was noted under the same conditions and the apoptosis cycle was thereby completed (43.7-fold vs. control). In the death receptor pathway, only DR4 gene expression showed a statistically significant increase at 48 hours with M1 (9.7-fold vs. control). TNF $\alpha$ gene expression was increased at 48 hours in the M1 group while Caspase- 8 was overexpressed at 24 hours with M2 administration (Figure 6). Gene expression of p21Chip1, a cell cycle checkpoint gene, triggers a prolonged G1 stage during the cell cycle and decelerates cell division by delaying the switch to synthesis stage (7). In our study, p21Chip 1 gene expression was increased by $7.44 \pm 1.8$-fold at 48 hours with M1 administration compared to the control group. This suggests that cells stop the cycle to repair the DNA damage, i.e. allow time for the DNA repair via cell cycle arrest (8).

\section{Discussion}

Heavy metals cause damages in cells both physiological and molecular level. Excess production of reactive oxygen species is one of the effects of toxic metal damage. As a result of insufficient antioxidant system, oxidative stress and related DNA damage occur. In our study, the significant increases in the expressions of the antioxidant enzymes suggest that the metal mixes administered to HAVSMC caused generation of reactive oxygen species and activated the antioxidant system to detoxify these toxic species. Reactive oxygen species cause DNA damage as well as several biologically important macromolecules in the cell. The RAPD band polymorphism determined in this study, is thought to be related to the DNA damage and genomic template instability resulting from the effect of toxic metal mixes $(9,10)$. When DNA damage occurs in cells, it can be repaired through the activation of the repair pathway. We determined EXO1 gene expression as a DNA repair gene and the findings indicate that DNA damage and effectiveness of repair change in correlation with time as well as concentration. Misfolded and unfolded proteins that occur due to oxidative stress and DNA damage in cells are identified by heat-shock proteins (HSPs), and are either repaired or degraded. In our study, the changes in the expressions of the HSPs suggests that misfolding of proteins occurs due to the toxicity effect of metal mixture in HAVSMC.

In terms of the association between cardiovascular cells and apoptosis, clinical studies have reported that apoptosis 
occurring in human aortic smooth muscle cells may trigger various conditions including atherosclerosis, arrhythmia, hypertension, aneurysm, angioplasty restenosis and tachycardia (11). Apoptosis in these cells is also associated with acute events such as rupture, coagulation, vascular remodeling, medial atrophy and calcification (12). Therefore, the apoptotic processes in HAVSCM cells are thought to be important in terms of cardiovascular disease.

\section{Conclusion}

In conclusion, our results showed oxidative stress and genotoxicity in aortic smooth muscle cells in a concentrationand time-dependent manner following the administration of a heavy metal mix consisting of $\mathrm{Cd}, \mathrm{Fe}, \mathrm{Cu}$ and $\mathrm{Pb}$ at permissible limits in water for human consumption and at a 10-fold higher concentration. Additionally, apoptosis was noted with the effect of this genotoxicity. Lower levels of genotoxicity and apoptosis were observed at permissible concentrations (M1) for drinking water compared to the 10-times higher M2 concentration. However, due to the exposure to multiple stress factors and furthermore, owing to the bioaccumulation of metals in humans, we believe that these permissible limits are potentially genotoxic, and new and lower limits should be determined.

This study is the Master Thesis of first author and presented as poster at International Agricultural, Biological and Life Science Conference Edirne, Turkey on September 2-5, 2018.

\section{References}

1. Khan S, Cao Q, Zheng YM, Huang YZ, Zhu, YG. Health risks of heavy metals in contaminated soils and food crops irrigated with wastewater in Beijing, China. Environmental pollution. 2008; 152(3): 686-92.

2. Påhlsson AMB. Toxicity of heavy metals $(\mathrm{Zn}, \mathrm{Cu}, \mathrm{Cd}, \mathrm{Pb})$ to vascular plants. Water, air and soil pollution. 1989; 47(3-4): 287-319.
3. Wuana RA, Okieimen FE. Heavy metals in contaminated soils: a review of sources, chemistry, risks and best available strategies for remediation. Isrn Ecology. 2011; 402647.

4. Järup L. Hazards of heavy metal contamination. British medical bulletin. 2003; 68(1): 167-182 .

5. Panigrahi, A. Heavy metal toxicity. Everyman's Science (Indian Science Congress). 2014; 68(6): 418.

6. Britton RS, Leicester KL, Bacon BR. Iron toxicity and chelation therapy. International journal of hematology. 2002; 76(3): 219-28.

7. Doganlar O, Doganlar ZB. Effects of a mixture of volatile organic compounds on total DNA and gene expression of heat shock proteins in Drosophila melanogaster. Archives of environmental contamination and toxicology. 2015; 68(2): 395-404.

8. Doğanlar ZB, Doğanlar O, Tabakçıoğlu K. Genotoxic effects of heavy metal mixture in Drosophila melanogaster: expressions of heat shock proteins, RAPD profiles and mitochondrial DNA sequence. Water, air and soil pollution. 2014; 225(9): 2104

9. von Harsdorf R, Li PF, Dietz R. Signaling pathways in reactive oxygen species-induced cardiomyocyte apoptosis. Circulation. 1999; 99(22): 2934-41.

10. Dimmeler S, Zeiher AM. Reactive oxygen species and vascular cell apoptosis in response to angiotensin II and proatherosclerotic factors. Regulatory peptides. 2000; 90(1-3); 19-25.

11. Boyle JJ. Vascular smooth muscle cell apoptosis in atherosclerosis. International journal of experimental pathology. 1999; 80(4): 197-203.

12. Clarke MC, Figg N, Maguire JJ, Davenport AP, Goddard M, Littlewood TD, Bennett MR. Apoptosis of vascular smooth muscle cells induces features of plaque vulnerability in atherosclerosis. Nature medicine. 2006;. 12(9): 1075. 